\title{
Diagnosis and treatment of macrocytic anemia in a perinatal common marmoset: a case report
}

Jong-Min Kim 1,2,3,4, Jina Kwak ${ }^{4,5}$, Hyun-Jin Lim, ${ }^{4,5}$ Joo-II Kim ${ }^{4,5}$ and Byeong-Cheol Kang 4,5,6,7*

\begin{abstract}
Background: The common marmoset is widely used in current biomedical research for various research fields. We observed macrocytic anemia in a perinatal common marmoset with gradual weight loss and diarrhea. The objective of this case report is to describe the diagnosis and treatment of macrocytic anemia in a perinatal common marmoset.

Case presentation: A 7-year-old female common marmoset showed clinical signs of gradual weight loss and intermittent diarrhea beginning 3 months after giving birth. Macrocytic anemia was diagnosed due to a decreased red blood cell (RBC) count, low hemoglobin level, and increased mean corpuscular volume (MCV). Multivitamins containing cobalamin and folate were administered for 7 days, and the patient's RBC count recovered to near the normal range with this treatment.

Conclusions: Macrocytic anemia can be diagnosed by evaluating the MCV on a complete blood count (CBC) and cobalamin or folate levels and be treated by supplementation with cobalamin and folate. Such supplements may be needed during pregnancy and lactation in female common marmosets and/or in animals with chronic diarrhea.
\end{abstract}

Keywords: Macrocytic anemia, Cobalamin, Folate, Perinatal common marmoset

\section{Background}

Common marmosets (Callithrix jacchus) are New World nonhuman primates (NHPs) that have been widely used for biomedical research in neuroscience, aging, reproductive biology, behavior, and drug development and safety because of they are small in size, cost relatively little to keep, require little effort for husbandry, are easy to handle for routine clinical procedures, have rapid reproductive turnover, and have a lower incidence of zoonoses than other NHPs such as macaques or baboons [1]. Thus, veterinary management of common marmosets is important for herd control and to obtain qualifying research results.

\footnotetext{
*Correspondence: bckang@snu.ac.kr

${ }^{5}$ Graduate School of Translational Medicine, Seoul National University

College of Medicine, 101 Daehakro, Jongno-gu, Seoul 03080, Korea

Full list of author information is available at the end of the article
}

We observed macrocytic anemia in a perinatal common marmoset with symptoms of gradual weight loss and diarrhea. Macrocytic anemia is defined an increased mean corpuscular volume (MCV) of red blood cells (RBCs) and is induced by cobalamin (vitamin B12) or folate (vitamin B9) deficiency. The objective of this case report is to report the diagnosis and treatment of macrocytic anemia in a perinatal common marmoset.

\section{Case presentation}

The animal experiments were approved by the Institutional Animal Care and Use Committee (IACUC) of the Biomedical Research Institute at the Seoul National University Hospital (an Association for Assessment and Accreditation of Laboratory Animal Care (AAALAC)accredited facility; IACUC number: 20-0161-S1A1). We obtained a group of common marmosets from CLEA (Tokyo, Japan). A 7-year-old female common marmoset 
Table 1 CBC results of $17 \mathrm{Cj03}$

\begin{tabular}{lll}
\hline Parameter & $\begin{array}{l}\text { Day of diagnosis of } \\
\text { macrocytic anemia }\end{array}$ & $\begin{array}{l}\text { 1 week after } \\
\text { multivitamin } \\
\text { treatment }\end{array}$ \\
\hline WBC $\left(10^{3} / \mu \mathrm{l}\right)$ & 5.01 & 6.03 \\
Neutrophil $\left(10^{3} / \mu \mathrm{l}\right)$ & 1.02 & 2.58 \\
Lymphocyte $\left(10^{3} / \mu \mathrm{l}\right)$ & 3.45 & 2.81 \\
Monocyte $\left(10^{3} / \mu \mathrm{l}\right)$ & 0.21 & 0.43 \\
Eosinophil $\left(10^{3} / \mu \mathrm{l}\right)$ & 0.01 & 0.02 \\
Basophil $\left(10^{3} / \mu \mathrm{l}\right)$ & 0.27 & 0.02 \\
RBC $\left(10^{6} / \mu \mathrm{l}\right)$ & 3.73 & 5.39 \\
Hb $(\mathrm{g} / \mathrm{dl})$ & 9.7 & 13.6 \\
Hct $(\%)$ & 36.9 & 47.0 \\
MCV $(\mathrm{fL})$ & 98.7 & 87.3 \\
MCH $(\mathrm{pg})$ & 25.9 & 25.2 \\
MCHC $(\mathrm{g} / \mathrm{dL})$ & 26.2 & 28.9 \\
PLT $\left(10^{3} / \mu \mathrm{l}\right)$ & 765 & 976 \\
Reticulocyte $(\%)$ & 24.9 & 15.1 \\
\hline
\end{tabular}

Table 2 Blood chemistry results on the day of diagnosis of macrocytic anemia in 17Cj03

\begin{tabular}{ll}
\hline Parameter & Results \\
\hline TP $(\mathrm{g} / \mathrm{dl})$ & 5.9 \\
ALB $(\mathrm{g} / \mathrm{dl})$ & 3.4 \\
ALP $(\mathrm{U} / \mathrm{l})$ & 1526 \\
AST $(\mathrm{U} / \mathrm{l})$ & 88 \\
ALT $(\mathrm{U} / \mathrm{l})$ & 2 \\
$\mathrm{BUN}(\mathrm{mg} / \mathrm{dl})$ & 42.4 \\
$\mathrm{CRE}(\mathrm{mg} / \mathrm{dl})$ & 0.49 \\
$\mathrm{GLU}(\mathrm{mg} / \mathrm{dl})$ & 168 \\
TBIL $(\mathrm{mg} / \mathrm{dl})$ & 0.2 \\
$\mathrm{GGT}(\mathrm{U} / \mathrm{l})$ & 4 \\
TG $(\mathrm{mg} / \mathrm{dl})$ & 72 \\
TCHO $(\mathrm{mg} / \mathrm{dl})$ & 119 \\
LDH $(\mathrm{U} / \mathrm{l})$ & 220 \\
$\mathrm{Na}(\mathrm{mEq} / \mathrm{l})$ & 149 \\
$\mathrm{~K}(\mathrm{mEg} / \mathrm{l})$ & 4.8 \\
$\mathrm{Cl}(\mathrm{mEq} / \mathrm{l})$ & 107 \\
$\mathrm{Ca}(\mathrm{mg} / \mathrm{dl})$ & 7.3 \\
P (mg/dl) & 3.8 \\
\hline
\end{tabular}

(ID: 17Cj03) showed clinical signs of gradual weight loss (from 306 to $250 \mathrm{~g}$ ), intermittent diarrhea, depression, and a poor hair coat beginning 3 months after giving birth. A complete blood count (CBC) and biochemical analysis were performed for diagnosis (Tables 1 and 2). Macrocytic anemia was diagnosed due to a decreased $\mathrm{RBC}$ count, low hemoglobin level, and increased MCV. Multivitamins (1/10 tab, P.O., SID; Hi Well Premium
Multi Vitamins \& Mineral for Women ${ }^{\circledR}$, Hi Well Healthcare, Auckland, New Zealand, Table 3) were administered for 7 days, and a repeated $C B C$ was performed to monitor the patient's response to multivitamin treatment. Her $\mathrm{RBC}$ count recovered to near the normal range (Table 1).

\section{Discussion and conclusions}

Macrocytic anemia is divided into two forms, megaloblastic (hypersegmented neutrophils) and non-megaloblastic. The megaloblastic form is due to impaired DNA synthesis from folate and/or vitamin B12 deficiencies, while the non-megaloblastic moiety (absence of hypersegmented neutrophils) occurs from multiple mechanisms such as alcohol consumption (RBC toxicity), hereditary spherocytosis (impaired volume regulation increases red cell size), hypothyroidism and liver disease (due to lipid deposition in the cell membrane), and marked reticulocytosis from states of excess RBC consumption such as hemolysis or turnover in pregnancy or primary bone marrow disease [2]. A limitation of this case report is that we could not identify hypersemented neutrophils by blood smear at the time of anemia, so we could not differentiate macrocytic anemia into megaloblastic and non-megaloblastic forms in this case. If the $\mathrm{CBC}$ test shows macrocytic anemia, it will be very important to differentiate it by blood smear. However, since it was confirmed that the anemia was improved by the administration of vitamin B12 and folate, it can be said that this case was in megaloblastic form of macrocytic anemia.

The megaloblastic form of macrocytic anemia is induced by a low serum cobalamin or folate level. Evaluation of serum cobalamin and folate levels requires $0.8 \mathrm{ml}$ of serum ( $1.6 \mathrm{ml}$ of whole blood) in our test protocol. This is a relatively large blood volume to collect in a common marmoset, especially in an anemic animal. Thus, to evaluate serum cobalamin and folate levels, we alternatively selected an archived sample that was collected from a euthanatized 7-year-old female common marmoset (ID: $15 \mathrm{Cj08}$ ) with clinical signs of gradual weight loss (from 269 to $224 \mathrm{~g}$ ), chronic diarrhea, anemia, and the same history of disease onset after childbirth. This marmoset's cobalamin and folate levels were $133 \mathrm{pg} / \mathrm{ml}$ and $>120 \mathrm{ng} /$ $\mathrm{ml}$, respectively (Centaur XP, Siemens, USA). The reference ranges for these parameters from Parambeth et al.'s group were $322-2642 \mathrm{pg} / \mathrm{ml}$ for cobalamin and $54.8-786.4 \mathrm{ng} / \mathrm{ml}$ for folate [3]. Although this marmoset (15Cj08) did not show macrocytic anemia, cobalamin deficiency was detected. The reason why this marmoset (15Cj08) did not show macrocytic anemia despite having a low cobalamin level remains unknown. One of the possibilities may be that when less than $100 \mathrm{pg} / \mathrm{ml}$ of cobalamin level in humans is diagnosed as macrocytic anemia 
Table 3 Ingredients of 1 tab of multivitamins

\begin{tabular}{llllll}
\hline Ingredients & Content & Ingredients & Content & Ingredients & Content \\
\hline Vitamin A & $530 \mu \mathrm{g} \mathrm{RE}$ & Vitamin C & $350 \mathrm{mg}$ & Magnesium & $25 \mathrm{mg}$ \\
Vitamin B1 & $19 \mathrm{mg}$ & Vitamin D3 & $9 \mu \mathrm{g}$ & Manganese & $1 \mathrm{mg}$ \\
Vitamin B2 & $2.8 \mathrm{mg}$ & Vitamin E & $21 \mathrm{mg}$ & Selenium & $17 \mu \mathrm{g}$ \\
Vitamin B3 & $15 \mathrm{mg} \mathrm{NE}$ & Biotin & $39 \mu \mathrm{g}$ & Chromium & $0.5 \mathrm{mg}$ \\
Vitamin B5 & $22 \mathrm{mg}$ & Rutin Trihydrate & $25 \mathrm{mg}$ & Copper & $12 \mathrm{mg}$ \\
Vitamin B6 & $7.5 \mathrm{mg}$ & Calcium & $10 \mathrm{mg}$ & Zinc & Encapsulating aids \\
Vitamin B12 & $6 \mu \mathrm{g}$ & Iron & $12 \mathrm{mg}$ & & \\
Folic acid & $600 \mu \mathrm{g}$ & lodine & $160 \mu \mathrm{mg}$ & & \\
\hline
\end{tabular}

by cobalamin deficiency, so this individual is judged to be at the borderline of cobalamin deficiency. However, the patient in this case (17Cj03) likely had macrocytic anemia induced by cobalamin deficiency because she was in the same herd and had the history of disease onset after childbirth, clinical signs, and diet. In women, cobalamin deficiency during pregnancy and lactation is a public health problem in populations with low consumption of animal products, and balanced intake of cobalamin-folate is necessary during pregnancy and lactation to prevent unhealthy consequences [4]. Since the common marmosets in this report were also pregnant and lactating, they may have needed cobalamin and folate supplementation similar to humans.

Another reason for low cobalamin and folate levels is chronic diarrhea. Intestinal absorption of cobalamin occurs via several processes, and absorption of a complex of cobalamin and intrinsic factors occurs through specific receptors in the enterocytes of the ileum [5]. Ileal disease leads to damage or decreased expression of cobalamin receptors, ultimately leading to decreased absorption of cobalamin and depletion of the body's reserves. In addition, intestinal microbial imbalances caused by disease can reduce serum cobalamin levels because many bacteria compete to bind intestinal available cobalamin [6]. Folate is another water-soluble vitamin of the B-complex family. Chronic bowel disease impairs folate carriers, which reduces folate intake, leading to decreased serum folate concentrations [7]. Diarrhea was also present in this case, and it is thought that this diarrhea may have contributed to the deficiency of cobalamin and folate. Another differential diagnosis based on this marmoset clinical symptom (intermittent diarrhea and weight loss) is wasting marmoset syndrome (WMS). WMS is a disease unique to this species and its main symptoms include weight loss, decreased muscle mass, and chronic diarrhea [8]. In marmosets with symptoms of WMS, megaloblastic form of macrocytic anemia may occur, so careful management is necessary.
In conclusion, macrocytic anemia can be diagnosed by evaluating the $\mathrm{MCV}$ on a $\mathrm{CBC}$ and cobalamin or folate levels and be treated by supplementation with cobalamin and folate. Such supplements may be needed during pregnancy and lactation in female common marmosets and/or in animals with chronic diarrhea.

\section{Abbreviations \\ AAALAC: Association for Assessment and Accreditation of Laboratory Animal Care; CBC: Complete blood count; IACUC: Institutional Animal Care and Use Committee; MCV: Mean corpuscular volume; WBC: White blood cell. \\ Acknowledgements \\ This work was partly supported by the National Research Foundation of Korea (NRF) grant funded by the Korea government (MSIT) (Grant No. NRF- 2020R1A2C201310111). The authors would like to thank H.W. Jung and H.I. \\ Son for caring for all NHPs.}

\section{Authors' contributions}

JMK, JK, HJL, and JIK contributed to data acquisition, analysis, and interpretation as well as study conception and design. JMK contributed to the writing of the manuscript. BCK is responsible for the final approval of the manuscript. All authors read and approved the final manuscript.

\section{Funding}

This work was partly supported by the National Research Foundation of Korea (NRF) grant funded by the Korea Government (MSIT) (Grant No. NRF-2020R1A2C201310111).

Availability of data and materials

Not applicable.

\section{Declarations}

Ethical approval and consent to participate

This article does not contain any studies with human participants performed by any of the authors.

\section{Competing interests}

The authors of this manuscript have no competing interests.

\section{Author details}

${ }^{1}$ Xenotransplantation Research Center, Seoul National University College of Medicine, Seoul, Korea. ${ }^{2}$ Institute of Endemic Diseases, Seoul National University College of Medicine, Seoul, Korea. ${ }^{3}$ Cancer Research Institute, Seoul National University College of Medicine, Seoul, Korea. ${ }^{4}$ Department of Experimental Animal Research, Biomedical Research Institute, Seoul National University Hospital, Seoul 110-799, Korea. ${ }^{5}$ Graduate School of Translational Medicine, Seoul National University College of Medicine, 101 Daehakro, Jongno-gu, 
Seoul 03080, Korea. ${ }^{6}$ Biomedical Center for Animal Resource and Development, Seoul National University College of Medicine, Seoul, Korea. ${ }^{7}$ Designed Animal and Transplantation Research Institute, Institute of Green Bio Science Technology, Seoul National University, Pyeongchang-gun, Gangwon-do, Korea.

Received: 11 November 2021 Accepted: 14 February 2022

Published online: 28 February 2022

\section{References}

1. Mansfield K. Marmoset models commonly used in biomedical research. Comp Med. 2003;53(4):383-92.

2. Moore CA, Adil A. Macrocytic anemia. [Updated 2021 Jul 15]. In: StatPearls. Treasure Island (FL): StatPearls Publishing; 2022 Jan. Available from https://www.ncbi.nlm.nih.gov/books/NBK459295/.

3. Parambeth JC, Ross CN, Miller AD, Austad SN, Lidbury JA, Suchodolski JS, et al. Serum cobalamin and folate concentrations in common marmosets (Callithrix jacchus) with chronic lymphocytic enteritis. Comp Med. 2019;69(2):135-43.

4. Obeid R, Murphy M, Sole-Navais P, Yajnik C. Cobalamin status from pregnancy to early childhood: lessons from global experience. Adv Nutr. 2017:8(6):971-9.

5. Nielsen MJ, Rasmussen MR, Andersen CBF, Nexo E, Moestrup SK. Vitamin B-12 transport from food to the body's cells-a sophisticated, multistep pathway. Nat Rev Gastroenterol Hepatol. 2012;9(6):345-54.

6. Degnan PH, Taga ME, Goodman AL. Vitamin B-12 as a modulator of gut microbial ecology. Cell Metab. 2014;20(5):769-78.

7. Milman N. Intestinal absorption of folic acid - new physiologic \& molecular aspects. Indian J Med Res. 2012;136(5):725-8.

8. Yoshimoto T, Niimi K, Takahashi E. Tranexamic acid and supportive measures to treat wasting marmoset syndrome. Comp Med. 2016;66(6):468-73.

\section{Publisher's Note}

Springer Nature remains neutral with regard to jurisdictional claims in pub-

lished maps and institutional affiliations.

- fast, convenient online submission

- thorough peer review by experienced researchers in your field

- rapid publication on acceptance

- support for research data, including large and complex data types

- gold Open Access which fosters wider collaboration and increased citations

- maximum visibility for your research: over 100M website views per year

At BMC, research is always in progress.

Learn more biomedcentral.com/submissions 